\title{
Effect of Disodium Cromoglycate on Exacerbations of Asthma produced by Hyperventilation
}

\author{
PAUL SILAS CLARKE
}

British Medical fournal, 1971, 1, 317-319

\section{Summary}

The prophylactic inhalation of disodium cromoglycate lessens the exacerbations which occur in some asthmatic patients after voluntary hyperventilation. Reasons are given for considering this to be a possible mechanism for certain types of emotional exacerbation of the disease and for disodium cromoglycate giving sypmtomatic relief of asthma disproportionate to the improvement in routine measurements of ventilatory capacity. It is suggested that one clinical indication for giving disodium cromoglycate is to observe whether a fall in FEV $V_{1}$ occurs after two minutes hyperventilation.

\section{Introduction}

Disodium cromoglycate was originally described as a specific inhibitor of the results of reagenic antibody-antigen mechanisms in vitro (Cox, 1967). It does not appear to be a smoothmuscle relaxant or bronchodilator, nor does it neutralize any of the known chemical mediators of the anaphylactic type of reaction.

Altounyan (1967) showed that disodium cromoglycate previously inhaled as a powder had a prophylactic action in a subject known to have an attack of asthma on the inhalation of an aerosol of grass pollen solution. By use of a doubleblind cross-over trial in 10 patients with severe asthma requiring high doses of corticosteroids and considered to have an allergic basis to their asthma because of the presence of eosinophils (Lendrum, 1944) in the sputum, Howell and Altounyan (1967) showed that symptomatic improvement was obtained in all 10 cases; but in only four were spirometric measures improved. This discrepancy between subjective improvement and improvement of objective indices of ventilatory capacity appears to be a characteristic of disodium cromoglycate.

Apparently quite separate from its antiallergic action, disodium cromoglycate has been shown to lessen post-exercise asthma (Davies, 1968). Normal subjects have an increase in airflow resistance of the bronchi on hyperventilation (Newhouse et al., 1964; Sterling, 1968), and according to Curry (1947) bronchi of asthmatic subjects are hyperirritable and overreact to almost any stimulus. It therefore seemed reasonable to investigate whether hyperventilation produced an exacerbation of asthma. A demonstration that overbreathing can increase airways resistance would show one mechanism by which emotion can exacerbate the asthmatic state, since the latter is often accompanied by some degree of overbreathing. If disodium cromoglycate modified this effect the implication would be that it had an action against some types of emotional asthma, and that these have a common factor with post-exercise asthma. The mechanism in either case is at present obscure. It was therefore decided to investigate the prophylactic action of disodium cromoglycate on

Royal Hobart Hospital, Hobart, Tasmania

PAUL SILAS CLARKE, M.B., B.S., Honorary Allergist any attacks of asthma that might be provoked by hyperventilation.

\section{Patients and Methods}

Nineteen asthmatic patients who were ambulant and thought to be co-operative volunteered to participate in the study. The forced expiratory volume in one second $\left(F E V_{1}\right)$ was measured and repeated until consistent readings within \pm $10 \%$ were obtained. While seated the subjects were asked to breathe as hard as they could for exactly two minutes when the $\mathrm{FEV}_{1}$ was immediately remeasured. Readings were then taken every minute for eight minutes, after which an isoprenaline aerosol was administered if any decrease in the $\mathrm{FEV}_{1}$ remained. Five patients did not show a fall in the $\mathrm{FEV}_{1}$. Of these five, three had had no asthma for over a year, one had had no attack of asthma while being treated with disodium cromoglycate during the previous three months, and one had never had spontaneous asthma but had allergic rhinitis. In him experimental asthma had been induced by the inhalation of a nebulized solution of the appropriate allergen on several occasions.

Fourteen patients showed a fall in the $\mathrm{FEV}_{1}$. Six were males and eight were females. They were aged 11 to 59 , with a mean of 33 years, the extremes of age being excluded by chance and not selection. None of them had previously been treated with disodium cromoglycate. Each of these 14 was shown how to inhale disodium cromoglycate powder, using a special apparatus supplied by the makers (Spinhalers-Fisons). A further appointment was made and they were instructed to inhale $20 \mathrm{mg}$ of disodium cromoglycate every four hours, including during the night, for 24 hours before the next appointment. On arrival for the second test they inhaled a further $20 \mathrm{mg}$ of disodium cromoglycate, irrespective of when the last inhalation had been taken. Ten minutes later the hyperventilation tests were repeated.

\section{Results}

In all 14 cases showing a fall of the $\mathrm{FEV}_{1}$ on hyperventilation the fall was diminished but not prevented by the previous inhalation of disodium cromoglycate. The maximum fall usually occurred some minutes after hyperventilation, and this is similar to the pattern usually seen in post-exercise asthma. A typical series of readings with and without disodium cromoglycate is shown in Fig. 1.

The maximum falls in the $\mathrm{FEV}_{1}$ with and without the prophylaxis of disodium cromoglycate during the eight minutes following the two minutes' hyperventilation are shown in the Table. Columns 1 and 4 are the control measurements before hyperventilation. Columns 2 and 5 set out the maximum fall achieved after hyperventilation. Though there was usually an interval of about a week between tests the control $\mathrm{FEV}_{1}$ was similar in all patients except No. 7, who was in a better condition on the day of the experiment with disodium cromoglycate. There is a significant difference $(\mathrm{P}<0.005)$ in the mean of the maximum fall in the two series of experiments with and without disodium cromoglycate. The results are shown in Fig. 2. The Table shows that not 
Effect of Two Minutes' Voluntary Hyperventilation in 14 Asthmatic Subjects Before and After the Inhalation of Disodium Cromoglycate

\begin{tabular}{|c|c|c|c|c|c|}
\hline \multicolumn{3}{|c|}{ Before inhalation } & \multicolumn{3}{|c|}{ After inhalation } \\
\hline Control & $\underset{\text { Fall }}{\text { Maximum }}$ & $\begin{array}{l}\text { Fall after } \\
8 \text { minutes }\end{array}$ & Control & $\begin{array}{c}\text { Maximum } \\
\text { Fall }\end{array}$ & $\begin{array}{l}\text { Fall after } \\
8 \text { minutes }\end{array}$ \\
\hline \multicolumn{3}{|c|}{ FEV $_{1}$ (litres) } & \multicolumn{3}{|c|}{ FEV $_{1}$ (litres) } \\
\hline $\begin{array}{l}3 \cdot 8 \\
2 \cdot 2 \\
2 \cdot 3 \\
2 \cdot 0 \\
2 \cdot 2 \\
0 \cdot 5 \\
1 \cdot 4 \\
2 \cdot 5 \\
2 \cdot 0 \\
2 \cdot 0 \\
1 \cdot 3 \\
2 \cdot 6 \\
2 \cdot 2 \\
1 \cdot 4 \\
\end{array}$ & $\begin{array}{l}-2.0 \\
-0.7 \\
-1.1 \\
-1.1 \\
-0.8 \\
-0.3 \\
-0.9 \\
-1.2 \\
-0.6 \\
-0.7 \\
-0.8 \\
-1.4 \\
-1.0 \\
-0.5\end{array}$ & $\begin{array}{r}-1.8 \\
-0.6 \\
-1.1 \\
-1.1 \\
-0.7 \\
-0.1 \\
-0.9 \\
-1.2 \\
-0.6 \\
-0.6 \\
0.0 \\
-1.1 \\
-0.6 \\
-0.4\end{array}$ & $\begin{array}{l}3 \cdot 7 \\
2 \cdot 2 \\
1 \cdot 7 \\
2 \cdot 4 \\
2 \cdot 1 \\
0 \cdot 5 \\
2 \cdot 2 \\
2 \cdot 5 \\
1.9 \\
2 \cdot 1 \\
1.5 \\
2 \cdot 5 \\
2 \cdot 8 \\
1 \cdot 5\end{array}$ & $\begin{array}{l}-0.3 \\
-0.6 \\
-0.7 \\
-0.6 \\
-0.3 \\
-0.1 \\
-1.3 \\
-0.3 \\
-0.3 \\
-0.2 \\
-0.6 \\
-0.5 \\
-0.8 \\
-0.3\end{array}$ & $\begin{array}{r}+0.1 \\
+0.2 \\
-0.3 \\
-0.4 \\
-0.2 \\
-0.0 \\
-0.8 \\
-0.3 \\
0.0 \\
0.0 \\
+0.8 \\
-0.1 \\
-0.6 \\
-0.1 \\
-0.1\end{array}$ \\
\hline Total & $-13 \cdot 1$ & $-10 \cdot 8$ & Total & -6.9 & $-1 \cdot 7$ \\
\hline
\end{tabular}

Analysis by Student's test (one-tail test): Maximum fall, $t=3.397$ for 13 degrees of freedom $(P<0.005)$; Fall after 8 minutes, $t=5.067$ for 13 degrees of freedom $(\mathrm{P}<0.001)$

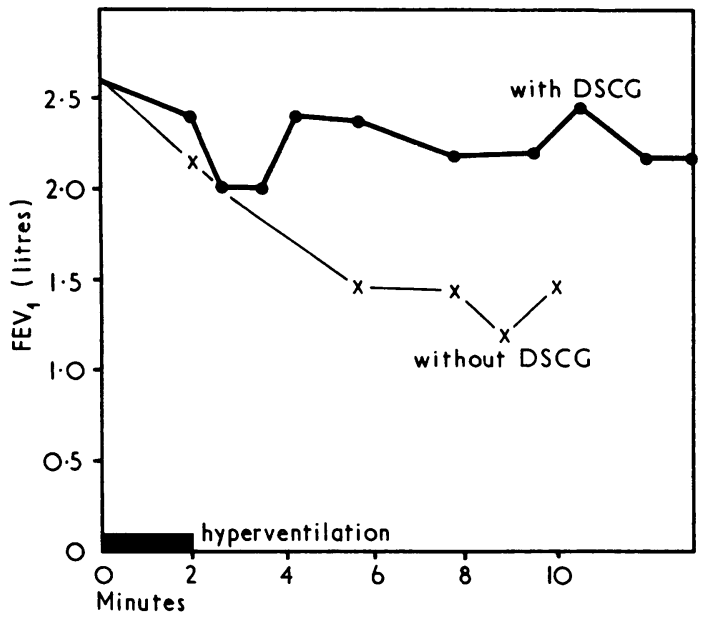

FIG. 1-Effect on $\mathrm{FEV}_{1}$ following two minutes' hyperventilation in an asthmatic subject.

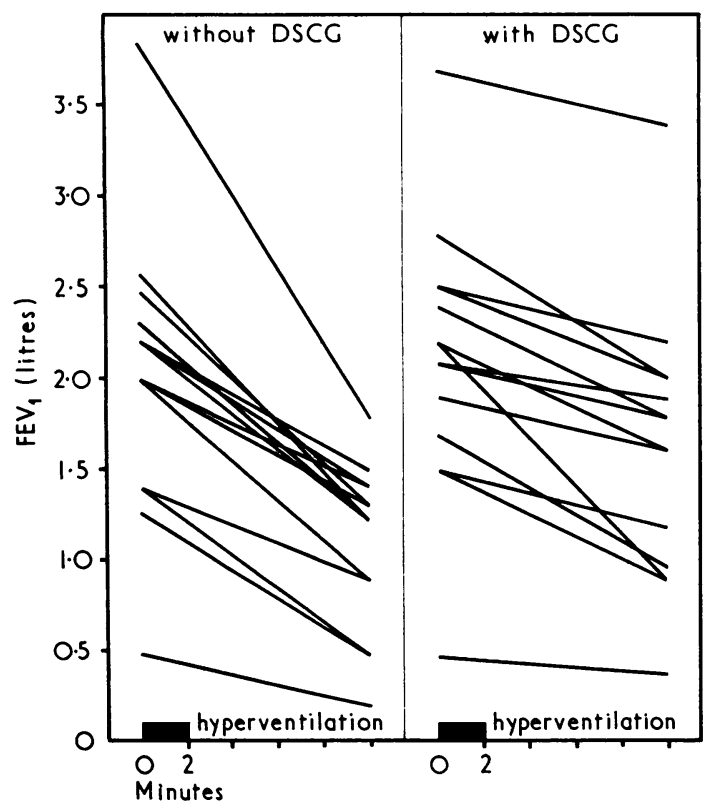

FIG. 2-Effect of disodium cromoglycate on exacerbations of asthma produced by hyperventilation. Maximum fall in FEV during eight minutes following hyperventilation $(\mathbf{P}<0.005)$.

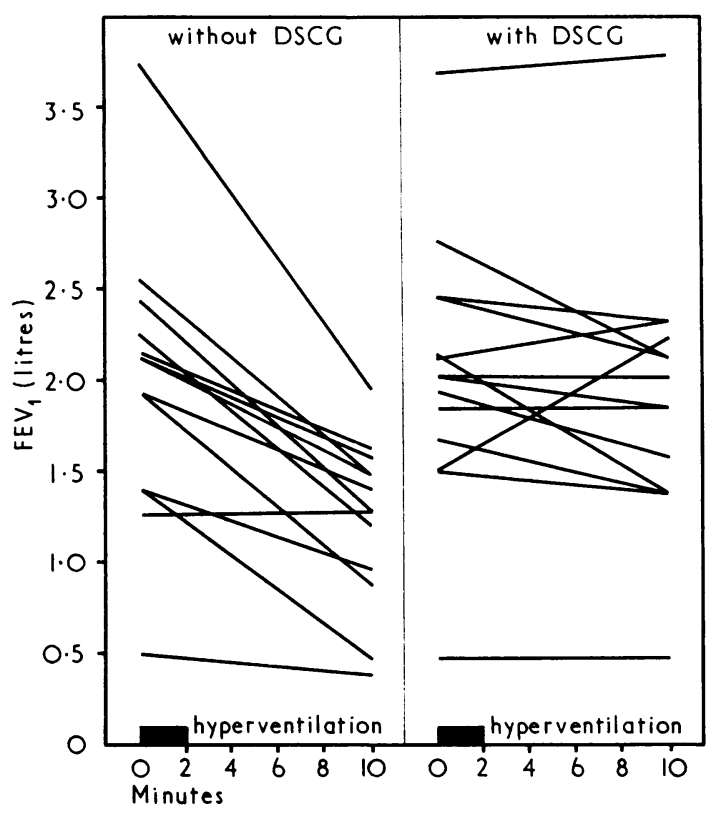

FIG. 3-Effect of disodium cromoglycate on duration of asthmatic exacerbations produced by hyperventilation. Comparison of fall in $\mathrm{FEV}_{1}$ eight minutes after hyperventilation with and without the prophylactic inhalation of disodium cromoglycate. $(\mathrm{P}<0.001)$.

only is the extent of the fall lessened but the recovery is hastened by the previous inhalation of disodium cromoglycate powder. Columns 3 and 6 show the difference in the fall of the $\mathrm{FEV}_{1}$ eight minutes after the cessation of hyperventilation (Fig. 3). The significance of the mean of the difference in the falls of the FEV $_{1}$ at eight minutes with and without disodium cromoglycate showed that $\mathrm{P}$ was $<0.001$.

\section{Discussion}

Variation in the difficulty of breathing is the hallmark of asthma, the patient being subjected to variable degrees of airways obstruction. These fluctuations subjectively make the patient more aware of the dyspnoea. If the exacerbations are removed and the disability is constant, adaptation in the patient's mode of life can be made; this is preferable to suffering inconvenient and sometimes unexpected attacks of asthma, each of which in the patient's mind may be a potential danger. Should such exacerbations be removed, patients might be expected to report a considerable degree of subjective improvement, reflected in any diary of symptoms which they might keep; but this feeling of improvement would not necessarily give a corresponding improvement in periodical objective measurements of ventilatory capacity.

Emotion of any sort may cause overbreathing. Patients with chronic asthma showed a significant rise in the minute volume of expired air as compared with the relaxed state when asked to recall the memory of an asthmatic attack $(\mathbf{P}<0.025)$ (Clarke, unpublished data). Under hypnosis the suggestion of an attack of asthma causes hyperventilation and a fall in the $F_{E V}$ (Clarke, 1970). This is evidence to show that a vicious circle can be set up as follows: the proprioceptive sensation of asthma causes overbreathing which leads to a rise in the airways resistance, which in turn increases the proprioceptive sensation of asthmatic distress. If this causes the patient to feel angry or frightened these emotions in themselves can further increase the airways resistance (Smith et al., 1970). It is suggested that the present study gives evidence of a mechanism for the emotional exacerbation of asthma already started by such external stimuli as antigens and non-specific irritants; this is in addition to the exacerbation caused as a con- 
ditioned reflex (Dekker and Groen, 1956; McFadden et al., 1969).

There is some contradiction in the literature on the clinical effects of disodium cromoglycate (Pepys et al., 1968; Herxheimer and Bewersdorff, 1969), but nearly all authors are agreed that it often gives useful subjective relief not always reflected by changes in the $\mathrm{FEV}_{1}$, the most common index used. Improvements in asthma need not always be reflected in the $\mathrm{FEV}_{1}$ (Woolcock and Read, 1965; Lane, 1969). Two authors state that the response to treatment by disodium cromoglycate cannot be predicted on allergic grounds alone (Campbell and Tandon, 1969; Ford, 1969). Its benefit in a specific case still appears to be unpredictable.

It is postulated that disodium cromoglycate can interfere with exacerbations of asthma which are emotional in nature brought about by hyperventilation consequent on the proprioceptive perception of asthma or other emotional cause, in addition to blocking the results of reagin-antigen union with its consequent asthma. Either mode of action may be at work separately or together at the same time. When an active allergic reaction is present both subjective and objective relief would be obtained. Otherwise the emotional exacerbations caused by hyperventilation together with the relief of postexercise asthma would give considerable subjective symptomatic and functional relief not necessarily reflected in periodical measurements of ventilatory capacity in the outpatient department. Indications for the use of disodium cromoglycate are still not definite, and it is suggested that one simple test indicating its use would be to observe whether a fall in the ventilatory capacity followed two minutes of maximum hyperventilation.

This work was partly supported by a grant-in-aid from the Asthma Foundation of Tasmania. My thanks are due to Professor A. Baikie and Dr. Alastair Campbell for critical encouragement, and to Mr. Peter Guilfoyle and Dr. A. Grassio for their help with the statistical analysis.

\section{References}

Altounyan, R. E. C. (1967). Acta Allergologica, 22, 487.

Campbell, A. H., and Tandon, M. K. (1969). Medical fournal of Australia, 2, 535 .

Clarke, P. S. (1970). Medical fournal of Australia, 1, 535.

Cox, J. S. G. (1967). Nature, 216, 1328.

.

Curry, J. J. (1947). Fournal of Clinical Investigation, 26, 430

Davies, S. E. (1968). British Medical fournal, 3, 593.

Dekker, E., and Groen, J. (1956). Fournal of Psychosomatic Research, 1, 58. Ford, M. R. (1969). Medical fournal of Australia, 2, 537.

Herxheimer, H., and Bewersdorff, H. (1969). British Medical fournal, 2, 220.

Howell, J. B. L., and Altounyan, R. E. C. (1967). Lancet, 2, 539.

Lane, D. J. (1969). British Medical fournal, 4, 710.

Lendrum, A. C. (1944). Fournal of Pathology and Bacteriology, 56, 441.

McFadden, E. R., jun., Luparello, T., Lyons, H. A., and Bleecker, E. (1969). Psychosomatic Medicine, $31,134$.

Newhouse, M. T., Becklake, M. R., Macklem, P. T., and McGregor, M. (1964). Fournal of Apolied Physiology, 19, 745.

Pepys, J., Hargreave, F. E., Chan, M., and McCarthy, D. S. (1968). Lancet, $2,134$.

Smith, M. M., Colebatch, H. J. H., and Clarke, P. S. (1970). American

Review of Respiratory Diseases, 102, 236.
Sterling, G. M. (1968). Clinical Science, 34, 277.

Woolcock, A. J., and Read, J. (1965). Lancet, 2, 1323.

\section{Gross Oedema in the Nephrotic Syndrome Treated with Frusemide in High Dosage}

British Medical fournal, 1971, 1, 319-321

\section{Summary}

Five grossly oedematous patients with nephrotic syndrome required frusemide in doses of $250 \mathrm{mg} /$ day or more. Two cases needed albumin infusions to initiate the diuresis. As oedema was removed renal function improved in four cases. There were no side effects. It is concluded that frusemide in the high doses used is a safe and effective diuretic.

\section{Introduction}

The safety and potency of frusemide has been established by more than five years' clinical experience throughout the world (Wertheimer et al., 1967; Dollery, 1968). In the absence of severe renal failure a satisfactory diuretic response is usually obtained with daily doses of $\mathbf{4 0 - 2 0 0 ~} \mathrm{mg}$, but occasionally much higher doses are required (Muth, 1968; Heiland et al., 1969). The safety of administration of these larger amounts of frusemide has not been adequately established in patients without severe renal failure, and therefore a series of five

Charing Cross Hospital Medical School, Fulham Hospital, London W.6 P. D. SNASHALL, B.SC., M.R.C.P., Medical Registrar (Present address : Medical School, University of Southampton, 125 Tremona Road, Southampton) grossly oedematous nephrotic patients who were treated with more than $200 \mathrm{mg}$ of frusemide per day were studied.

\section{Patients and Methods}

Two women and three men aged 16 to 50 who had failed to respond to conventional doses of frusemide were studied (Table I). All had the nephrotic syndrome with gross oedema and hypoalbuminaemia (less than $1.5 \mathrm{~g} / 100 \mathrm{ml}$ in four cases) and more than $5 \mathrm{~g}$ of urinary protein loss per 24 hours. In all cases the glomerular filtration rate was below normal at the onset of treatment. All subjects were normotensive. The study was mainly retrospective, the criterion for selection being that these patients needed over $250 \mathrm{mg}$ of frusemide per day. All patients treated at this hospital in the past two years who satisfied this criterion were included.

Treatment was begun with $40-80 \mathrm{mg}$ of frusemide daily, but as none of the patients responded the dose was doubled, usually at daily intervals until the diuresis began. The dose was then varied according to the diuretic response, requirements tending to decrease as the oedema was removed. In two patients (Cases 1 and 4 ) who were uraemic the diuresis was established only after plasma volume expansion with salt-poor albumin, $25 \mathrm{~g}$ of which was diluted in 500 $\mathrm{ml}$ of water in one case and in mannitol $10 \%$ in the other, and given daily for one week. Frusemide was added to the infusion. Spironolactone or triamterene was given largely for the potassium-sparing properties. Potassium requirements 